\title{
PENGARUH SUHU AIR PADA PROSES PENGGILINGAN KEDELAI (Glycin Max (L) Merril) TERHADAP KADAR PROTEIN SUSU DENGAN METODE SPEKTROFOTOMETRI UV-Vis
}

\author{
Yuni Fatisa, Maslinda \\ Jurusan Pendidikan Kimia, Fakultas Tarbiyah dan Keguruan UIN SUSKA-Riau
}

\begin{abstract}
ABSTRAK
Telah dilakukan penelitian pengaruh suhu air pada proses penggilingan kedelai terhadap kadar protein susu kedelai. Variasi suhu air yang digunakan dalam penelitian ini adalah: 30,40,60 dan $100{ }^{\circ} \mathrm{C}$. Untuk menentukan pengaruh suhu air pada proses penggilingan kedelai terhadap kadar protein susu kedelai digunakan analisis data anova satu arah dengan taraf signifikansi $5 \%$ dan $1 \%$.Hasil analisis menunjukkan bahwa variasi suhu air yang digunakan pada proses penggilingan kedelai berpengaruh nyata terhadap kadar protein susu kedelai. Dimana kadar protein pada suhu $30^{\circ} \mathrm{C}$ adalah $2,583 \%, 40^{\circ} \mathrm{C}$ adalah $3,789 \%, 60^{\circ} \mathrm{C}$ adalah $4,415 \%, 80{ }^{\circ} \mathrm{C}$ adalah 3,876 dan $100{ }^{\circ} \mathrm{C}$ adalah $2,189 \%$. Dari hasil penelitian diperoleh kadar protein tertinggi didapat dari penggilingan yang menggunakan air suhu $60{ }^{\circ} \mathrm{C}$.
\end{abstract}

Kata Kunci: suhu air, protein, susu kedelai

\section{PENDAHULUAN}

Kedelai (Glycine max (L) Merril) merupakan salah satu tanaman sumber protein yang penting di Indonesia. Diantara jenis kacang-kacangan, kandungan protein kedelai paling tinggi (Sudarsih \& Kurniati, 2009). Kedelai juga mengandung isoflavon yang memiliki efek menguntungkan kesehatan manusia, diantaranya mencegah kanker, penyakit jantung, osteoporosis dan menopausal symptoms (Dubravka \& Mirjana, 2007)

Bagian paling penting dari tanaman kedelai adalah bijinya. Biji kedelai dapat diolah menjadi berbagai jenis produk olahan. Produk olahan kedelai dapat diklasifikasikan menjadi dua kelompok, yaitu produk fermentasi dan nonfermentasi. Produk non fermentasi hasil olaghan tradisional yang berpotensi dipasaran diantaranya tahu dan susu kedelai, sedangkan produk fermentasi berupa tempe, kecap dan tauco. Produk hasil olahan industri modern sebagian besar terdiri atas produk non fermentasi, beberapa diantaranya adalah minyak kedelai, tepung kedelai dan daging sintetik atau TVP (Texturized Vegetable Protein). Sedangkan produk fermentasi hasil pengolahan industri modern diataranya yogurtr kedelai (soyghurt) dan keju kedelai (soycheese) (Koswara, 1995).

Susu kedelai merupakan minuman bergizi tinggi dan sejak abad ke-2 SM sudah dibuat di
China. Dari sana kemudian berkembang ke Jepang dan setelah Perang Dunia II masuk ke Negara-negara Asean. Susu kedelai merupakan salah satu produk kedelai yang memiliki kelebihan, antara lain relative lebih murah dibandingkan susu sapi, bergizi tinggi, sesuai bagi penderita lactose intolerance, tidak mengandung koleterol dan tidak menyebabkan alergi. (Ginting, dkk, 2009). Jika dibandingkan dengan susu sapi, protein susu kedelai mempunyai susunan asam amino yang mirip susu sapi sehingga dapat menjadi alternative pengganti susu sapi. Susu kedelai adalah cairan berwarna putih seperti susu sapi, tetapi dibuat dari ekstrak kedelai. Untuk memperoleh susu kedelai yang layak dikonsumsi manusia, diperlukan beberapa persyaratan, diataranya bebas rasa lungu, bebas antitripsin dan memiliki stabilitas koloid yang mantap (Koswara, 1995).

Dalam pembuatan susu kedelai di lakukan melalui beberapa tahapan yakni perendaman, perebusan, penghilangan kulit ari, penggilingan dan penyaringan. Pada proses penggilingan, air digunakan sebagai pelarut. Hal ini dikarenakan protein yang terdapat pada kedelai berupa legumelin dan glisin. Legumelin merupakan kelompok albumin yang bersifat larut dalam air sedangkan glisin mnerupakan kelompok globulin yang bersifat tidak larut dalam air (Maryam S, 2007). Dari segi struktur susunan molekul, 
protein tersebut merupakan protein globular. Salah satu faktor yang mempengaruhi kelarutan protein globular adalah temperatur.

Protein merupakan salah satu zat gizi yang berubah oleh pemanasan. Kebanyakan protein pangan terdenaturasi jika dipanaskan pada suhu yang moderat $\left(60-90^{\circ} \mathrm{C}\right)$ selama satu jam atau kurang. Dari penelitian sebelumnya, didapatkan bahwa suhu perendaman berpengaruh terhadap kadar protein susu kedelai. Jika suhu perendaman melebihi suhu optimum, maka kadar protein semakin menurun (Sundarsih dan Kurniati, 2009). Denaturasi akan menyebabkan perubahan struktur protein dimana pada keadaan terdenaturasi penuh, hanya struktur primer protein saja yang tersisa, protein tidak lagi memiliki struktur sekunder, tersier dan kuartener. Akan tetapi belum terjadi pemutusan ikatan peptida pada kondisi terdenaturasi penuh.Denaturasi protein yang berlebihan dapat menyebabkan insolubilitasi yang dapat mempengaruhi sifat-sifat fungsional protein yang tergantung pada kelarutannya.

Berdasarkan uraian latar belakang diatas, maka kami lakukan penelitan dengan tujuan untuk mengetahui pengaruh suhu air pada proses penggilingan kedelai (Glycine Max (L) Merril) terhadap kadar protein susu dengan metode Spektrofotometri UV-VIS.

\section{METODOLOGI PENELITIAN}

\section{Alat dan Bahan}

Alat yang digunakan dalam penelitian ini adalah termometer, spektrofotometer, Sentrifus, $\mathrm{pH}$ meter, blender, dan alat-alat gelas. Bahan yang digunakan adalah kedelai kering, $\mathrm{CuSO}_{4} .5 \mathrm{H}_{2} \mathrm{O}$, Kalium natrium tartarat $\left(\mathrm{KNaC}_{4} \mathrm{H}_{4} \mathrm{O}_{6} .4 \mathrm{H}_{2} \mathrm{O}\right), \mathrm{NaOH} 10 \%$, Amonium Sulfat, Bovin Serum Albumin (BSA), aquades.

\section{Pembuatan susu kedelai}

Pembuatan susu kedelai menggunakan Metode Pusat Pengembangan Teknologi Pangan (Pusbangtepa IPB), sebagai berikut: Kedelai sebanyak 25 gram dicuci bersih, kemudian direndam dalam baskom yang berisi air selama kurang lebih 8 jam pada suhu kamar. Kedelai yang telah direndam selanjutnya direbus pada suhu $80^{\circ} \mathrm{C}$ selama 15 menit. Kedelai yang telah direbus dicuci dan dihilangkan kulit arinya. Selanjutnya kedelai digiling dengan blender yang telah diisi dengan $200 \mathrm{ml}$ air pada suhu air $30{ }^{\circ} \mathrm{C}$ selama lima menit. Perlakuan yang sama dilakukan pada kedelai yang diblender untuk suhu 40, 60, 80, $100{ }^{\circ} \mathrm{C}$. Bubur kedelai disaring, sehngga diperoleh susu kedelai.

\section{Pengukuran kadar protein}

Pengukuran kadar protein dilakukan dengan Spektrofotometer UV-Vis, dengan cara: sampel protein dari susu kedelai diendapkan dengan penambahan kristal ammonium sulfat (sampai mendekati kejenuhan ammonium sulfat dalam larutan). Protein yang mengendap disentrifugasi dengan kecepatan 11.000 rpm selama 10 menit, pisahkan supernatannya. Endapan yang merupakan protein kemudian dilarutkan kembali dengan dapar asetat $\mathrm{pH} 5$ sampai $10 \mathrm{ml}$. Selanjutnya $0,9 \mathrm{ml}$ sampel ditambahkan pereaksi biuret $0,8 \mathrm{ml}$ dan ditambahkan 1,3 ml larutan dapar asetat $\mathrm{pH} 5$, didiamkan selama 10 menit pada suhu kamar.

\section{HASIL DAN PEMBAHASAN}

Dalam penelitian ini, pembuatan susu kedelai mengikuti metode Pusbangtepa ITB yang diawali dari perendaman kedelai selama 8 jam. Perendaman ini bertujuan untuk melunakkan struktur selular kedelai sehingga mudah digiling. Setelah direndam, dilanjutkan dengan perebusan kedelai pada suhu $80^{\circ} \mathrm{C}$ selama 15 menit, untuk menginaktifkan antin tripsin yang terdapat pada kedelai, menghilangkan bau lungu yang disebabkan oleh kerja enzim lipoksigenase yang terdapat pada biji kedelai, dimana enzim tersebut bereaksi dengan lemak sewaktu dinding sel pecah oleh penggilingan, terutama jika penggilingan dilakukan secara basah dengan suhu dingin. Enzim lipoksigenase mudah rusak oleh panas. Selain itu, perebusan juga dapat mempermudah pengelupasan kulit ari.

Selanjutnya kedelai digiling menggunakan blender dengan air dengan perbandingan 1: 8 . Ekstraksi protein kedelai dengan air ini dilakukan untuk mengekstrak protein dari kedelai. Pada proses ekstraksi terbentuk dua fase seimbang 
antara refinat dan ekstrak, dimana fase refinat berupa ampas mengandung protein yang bersifat tidak larut dalam air seperti globulin, sedangkan fase ekstrak mengandung protein yang bersifat larut dalam air seperti legumelin yang merupakan protein kelompok albumin yang umumnya terdapat pada polong-polongan.

Pada proses penggilingan kedelai ini, suhu air yang digunakan bervariasi yaitu 30, 40, 60, 80 dan $100{ }^{\circ} \mathrm{C}$. Kemudian dilanjutan dengan penyaringan sehingga diperoleh susu kedelai.

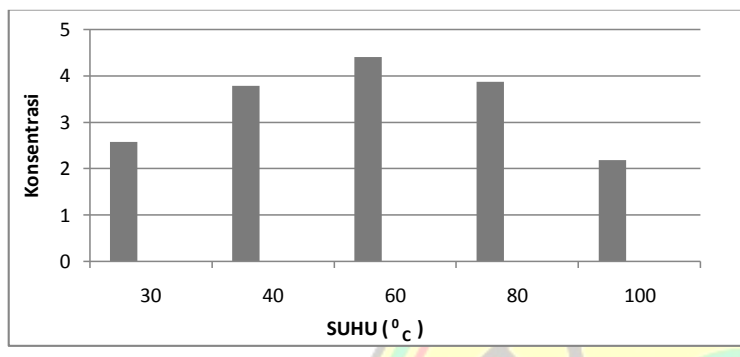

Pada Gambar. Di atas terlihat bahwa proses penggilingan kedelai dengan menggunakan air dengan suhu $30{ }^{\circ} \mathrm{C}$ sampai $60{ }^{\circ} \mathrm{C}$ kadar protein mengalami peningkatan, sedangkan pada suhu 80 ${ }^{0} \mathrm{C}-100{ }^{0} \mathrm{C}$ kadar protein mengalami penurunan. Kadar protein terendah terdapat pada suhu $100{ }^{\circ} \mathrm{C}$ yaitu $2,189 \%$, sedangkan kadar protein tertinggi $4,415 \%$ diperoleh pada suhu $60{ }^{\circ} \mathrm{C}$.

Hal ini berarti bahwa kadar protein susu kedelai bertambah dengan bertambahnya suhu, dan suhu air yang optimum pada proses penggilingan kedelai adalah suhu $60{ }^{\circ} \mathrm{C}$.

Dari hasil uji anova satu arah diperoleh taraf signifikan $5 \%$ dan $1 \%$, yang berarti variasi suhu yang digunakan pada proses penggilingan berpengaruh nyata terhadap kadar protein susu kedelai. Sedangkan dari hasil uji Tukey's HSD menunjukkan suhu air optimum digunakan saat menggiling kedelai adalah $60{ }^{\circ} \mathrm{C}$.

Berpengaruhnya suhu air pada proses penggilingan kedelai dikarenakan penambahan air saat menggiling tidak lain merupakan proses pelarutan protein globular (legumelin) yang terdapat pada kedelai, adanya interaksi antara molekul pelarut polar atau air dengan molekul protein polar (legumelin) yang ada dalam kedelai akan mengakibatkan terlarutnya protein tersebut.
Pertambahan suhu air yang digunakan pada saat menggiling akan menyebabkan bertambahnya gerakan molekul-molekul yang berinteraksi, dengan bertambahnya molekul-molekul yang berinteraksi maka tumbukan antara molekul satu dengan lainnya akan bertambah. Dampak dari proses interaksi yang semakin bertambah, maka protein legumelin yang terlarut dalam air akan semakin bertambah.

Akan tetapi, pada suhu diatas $60{ }^{\circ} \mathrm{C}$ kadar protein semakin berkurang, hal ini dikarenakan ikatan protein diatas suhu $60{ }^{\circ} \mathrm{C}$ mulai mengalami denaturasi (Sundarsih dan Kurniaty, 2009). Pada penelitian lain yang mengkaji cara pengolahan dengan suhu tinggi pada tempe kedelai hitam terhadap kualitas protein in vitro yaitu pengolahan dengan perebusan, pengukusan, penggorengan dan pemanggangan mendapatkan bahwa kadar protein (bobot kering) tertinggi pada tempe kedelai hitam terdapat pada proses pengukusan dan terendah pada penggorengan (Nurhidajah, dkk). Protein yang terdenaturasi berkurang kelarutannya, sehingga penggilingan pada suhu ini dan suhu yang lebih tinggi, kandungan protein susu kedelai lebih rendah. Struktur protein yang terdenaturasi biasanya akan rusak, lapisan molekul protein bagian dalam yang bersifat hidrofobik berbalik keluar, sedangkan bagian luar yang bersifat hidrofilik terlipat ke dalam sehingga mengalami koagulasi (Winarno, 2004).

\section{KESIMPULAN}

Variasi suhu air yang digunakan pada proses penggilingan kedelai berpengaruh terhadap kadar protein susu kedelai. Semakin tinggi suhu air, semakin tinggi pula kadar protein yang dihasilkan, namun penggilingan kedelai dengan suhu diatas $60{ }^{\circ} \mathrm{C}$ menunjukkan penurunan kadar protein, karena protein mengalami denaturasi. Suhu optimum yang diperoleh dalam penelitian ini adalah suhu $60{ }^{\circ} \mathrm{C}$.

\section{DAFTAR PUSTAKA}

Dubravka Stajner, Mirjana Milosevic, Boris. M. Popovic, Irradiation Effects On Phemolic Content, Lipid and Protein Oxidation And Scavenger Ability Of SoybeenSeeds. 
International Journal Of Moleculer Science, Serbia 2007.

Ginting, E, dkk, Varietas Unggul Kedelai Untuk

Bahan Baku Industri Pangan, Jurnal Litbang

Pertanian,. Malang, 2009.

Maryam, Siti, Penentuan Suhu Optimum pada

Saat Menggiling Kedelai untuk

Menghasilkan Tahu Berkualitas JPPSH I (2) 2007

Nurhidajah , dkk, Daya Terima dan Kualitas In Vito Tempe Kedelai Hitam (Glicine soja) yang diolah Pada Suhu Tinggi, Tesis Program Magister Gizi Masyarakat
Universitas Diponegoro Semarang

Sundarsih Dan Kurniati, Yuliana, Pengaruh Suhu dan lama Perendaman Kedelai Pada Tingkat Kesempurnaan Ekstraksi Protein Dalam Proses Pembuatan Tahu. Makalah Penelitian, Teknik Kimia Fakultas Teknik Kimia Universitas Diponegoro, Semarang, 2009.

Koswara, Yuliana, Teknologi Pengolahan Kedelai, Pustaka Sinar Harapan, Jakarta, 1995.

Winarno, Kimia Pangan dan Gizi, PT Gramedia: Jakarta

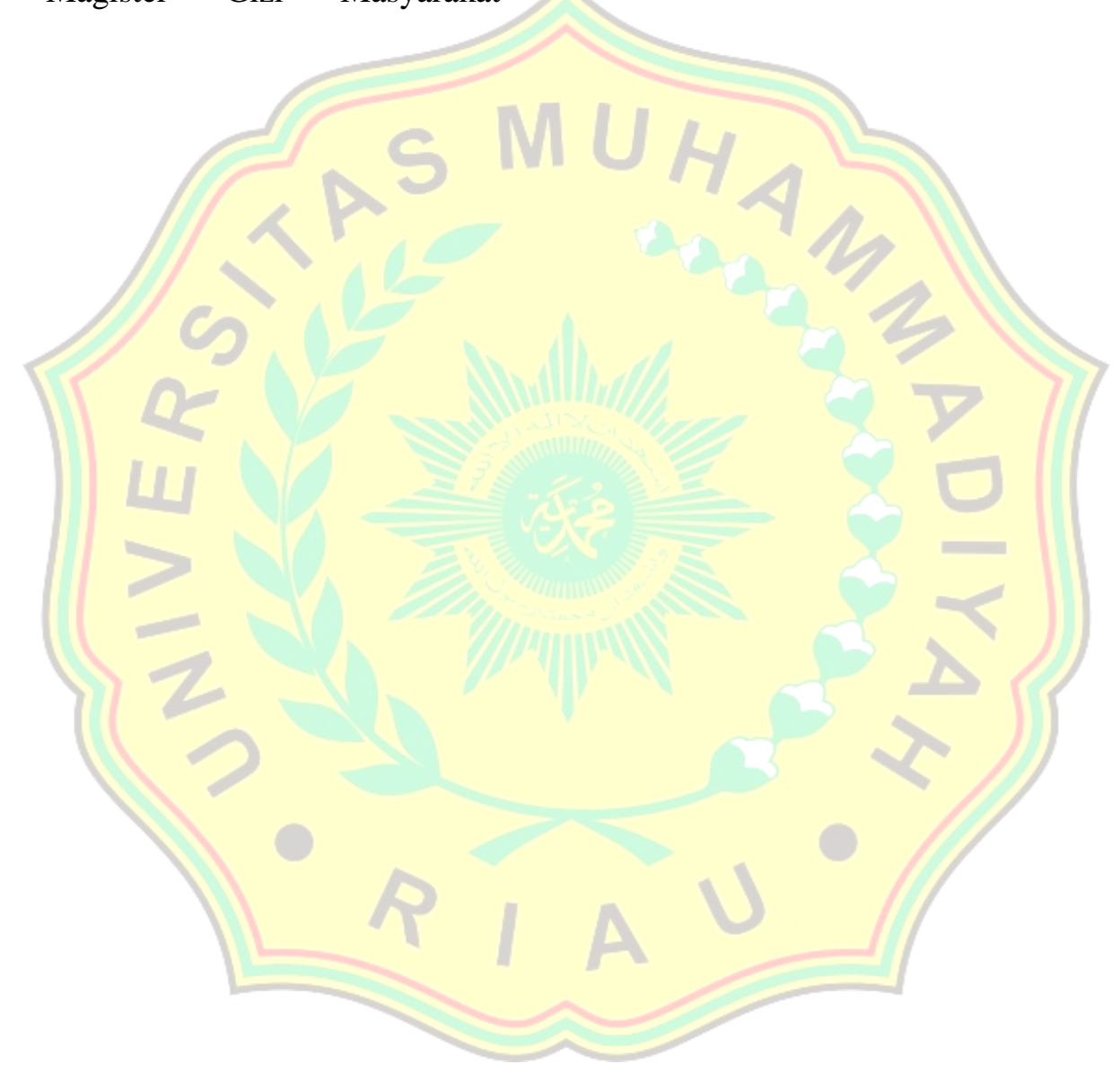

